\title{
Some characteristic of Rhizoctonia spp. in sharp eyespot of wheat
}

\section{HELENA FRUGAL-WĘGRZYCKA, JAN and EWA ADAMIAK}

\author{
Department of Agricultural Microbiology, Olsztyn University of Agriculture and Technology, \\ 10-718 Olsztyn, PI. Lodzki 3, Poland
}

\begin{abstract}
Furga l-Węgrzy eka H., A da mi a k J., A da mi a k E.: Some characteristic of Rhizoctonia spp. in sharp eyespot of wheat. Acta Mycol. 31 (2): 199-208, 1996.

Isolates of Rhizoctonia sp. with multinucleate and binucleate cells were obtained from sharp eyespot lesions on wheat culms in Olsztyn region. (NE Poland). These isolates were compared to isolates of AG-4 and GAG-1 testers with reference to cultural morphology of colony, growth rate, hyphal anastomosis and pathogenicity to wheat seedlings. The wheat binucleate isolates were similar in morphology of colonies and anastomosed with the Ceratobasidium anastomosis group GAG-1 tester isolates of $R$. cerealis. Growth rates on PDA ranged from 9 to $11 \mathrm{~mm} / 24 \mathrm{~h}$ for wheat isolates and from 1 to $11 \mathrm{~mm} / 24 \mathrm{~h}$ for tester isolates GAG-1 of $R$. cerealis. The wheat multinucleate isolates were similar in morphology of colonies and anastomosed with Rhizoclonia solani Kühn group AG-4 tester isolate. $R_{+}$solani AG-4 isolates were morphologically distinct from the $R$. cerealis isolates. These isolates on PDA were dark and grow rapidly $\left(20-30 \mathrm{~mm}\right.$ diam. $\left./ 24 \mathrm{~h} / 20^{\circ} \mathrm{C}\right)$ and significantly contrasted with slowly growing white-creamy isolates of R. cerealis (GAG-1). Isolates of $R$. solan (AG-4) and $R$. cerealis (GAG-1) developed sharp eyespot lesions on culms and white head symptoms typical of the disease. None of the wheat isolates of $R$. cerealis (GAG-1) caused root-rot on wheat seedlings. In the present work the classification system of vegetative groups of Rhizoctonia spp. in present work is also discussed.
\end{abstract}

Key words: Triticum aestivum, Rhizoctonia solani, R. cerealis, anastomosis group, sharp eyespot disease, cultural characteristes, pathogenicity.

\section{INTRODUCTION}

Sharp eyespot is a common disease of Triticum aestivum in the temperate regions of the world. The disease generally and frequently occurs in association with more damaging rot-stem diseases (B r u e h l, 1951; P i t t, 1964; R e i n e c k e, Feh rm a n n, 1979; Li p ps, Herr, 1981, 1982; C a r l ing, S um mer, 1982; Clarkson, Cook, 1983; Holli ins, Je 11 is, S c ot t, 1983; Hollins, S cot t, 1983; De a c o n, S cott, 1985; M oen, Harris, 1985; C a r l in g, Le in er, Ke bler, 1986; Og os hi. Cook. B a s set t, 1990). 
The first report of sharp eyespot on wheat was presented by S p r a g u e (1934). Later S p r a g u e (1937) attributed the disease to the presence of Rhizoctonia sp. Based on morphological characteristics B I a i r (1942) identified the fungus isolated from sharp eyespot lesions on wheat stems from Canada and England as Rhizoctonia solani Kühn. Further works (G1 y n n e, 1950; P i t t, 1964; C a r 1 i n g, S u mm e r, 1992; C l a r k s o n, C o o k, 1983) supported Blair's identification of $R$. solani as the casual agent of sharp eyespot. Recently, S te r n and J o n e s (1978) indicated $R$. solani as the cause of sharp eyespot and assigned it to the hyphal anastomosis group AG-4 as erected by P a r a m e t e r, W h i t n e y, P l a t t (1967). $\mathrm{S}$ te r $\mathrm{n}$ and $\mathrm{J}$ o n e s (1978) reported that only AG-4 isolates of $R$. solani caused damping-off and sharp eyespot lesions on wheat. In 1977, V a n d e r H o e v e n described a new species, $R$. cerealis, as the cause of sharp eyespot lesions on wheat in the Netherlands. $R$. cerealis differs from $R$. solani in having predominantly binucleate hyphal cells and a relatively slow growth rate. Thus, two different fungi resembling one another in morphological feature cause similar symptoms on small grains (P a r a m e ter, Whitne y, Pl a t t, 1967; S h e r w o o d, 1969; Pa r ameter, 1970; Og oshi, 1972, 1975, 1985; Og os hi, O miki, Sakai, 1979; Og os hi, Omiki, Araki, 1983; Burpee, 1980; Burpree, Sanders, Cole, 1980; Martin, Luc as, 1984; Murray, Burpree, 1984; Carling, Leiner, Kebler, 1986; Oniki, O g os hi, Araki, 1986; Kat a ri a, Hoffman, 1988; Mordue, Carrah, Bridge, 1989; S neh, Burpree, O g os hi, 1991; C a r ling, Sum mer, 1992).

Grouping based on hyphal anastomosis among isolates having common biological affinities has greatly facilitated the identification of $R$. solani. B u r p r e e, $\mathrm{S}$ a n d e r s, C o l e (1980) observed hyphal anastomosis among isolates of Ceratobasidium cornigerum (Bourd) Rogers and related fungi having Rhizoctonia imperfect states. Based on hyphal pairing, seven Ceratobasidium anastomosis groups (GAG) were established. Within each GAG, little homogenity occurred among isolates with respect to host, except for GAG-1 isolates, which were associated with members of the Gramineae (Mur r a y, Burpree, 1984; On i k i, Ara k i, 1986; Kat a ri a, H of m a n, 1988; Sneh, Burpree, Ogos hi, 1991; Burpree, M a r t i n, 1992). B u r p r e e (1980) later found that isolates assigned to CAG-1 anastomosed with the type culture of $R$. cerealis, demonstrating that isolates of $R$. cerealis comprise a common anastomosis group CAG-1. He reported that isolates of $R$. cerealis from the United States and elsewhere were the cause of yellow patch of turfgrass. $R$. cerealis has been reported as the cause of sharp eyespot in the Netherlands, Germany, and South Africa (S c o t t, V is s e r, R u z e n a c h t, 1979; Li p p s, Herr, 1982; H oll i n s, S c ot t, 1983; M oe n, Harr is, 1985; De a con, Scott, 1988; Kataria, Hof fma n, 1988; Ogosh i, Cook, Bassett, 1990).

Plants with white heads and sharp eyespot lesions on the base of culms were found in several locations during a survey of wheat fields in Poland. Fungi resembling $R$. solani were isolated from these lesions. However, these isolates grew more slowly and had narrower hyphae than typical isolates of $R$. solani.

The purpose of this study was to identify the isolates obtained from sharp eyespot lesions and to determine their pathogenicity to wheat. 


\section{MATERIALS AND METHODS}

I solat ion and sources. Wheat culms with sharp eyespot lesions were collected from commercial fields in Olsztyn region and plots in Experimental Station Bałcyny in the years 1994-1996. Plants samples were obtained from the experimental fields under the crop rotation: sugar beet-spring wheat-winter barley amended with different organic manures (biological compost, straw and stable manure) and four levels of mineral nitrogen $(0,30,60,90,120 \mathrm{~N} /$ hectare $)$. Spring wheat cultivar 'Inga' was cropping as follows: 1994 - wheat, 1995 - sugar beet following wheat, 1996 - spring barley following wheat.

The crop rotation was established in 1994 year. Rhizoctonia cerealis and $R$. solani were isolated from diseased plant using standard procedure.

Selective media. 1) Ko-Hora medium amended: benomyl -500 mg/l, prochloraz $-500 \mathrm{mg} / \mathrm{l}$ (K o, H o r a, 1971).

2) $2 \%$ water agar (WA) amended with ethanol $-20 \mathrm{ml} / \mathrm{l}, \mathrm{NaNO}_{3}-5 \mathrm{~g} / \mathrm{l}, \mathrm{KH}_{2} \mathrm{PO}_{4}-$ $0.5 \mathrm{~g} / \mathrm{l}$ ( T r u j i 11 o et al., 1987).

3) $2 \%$ WA amended with fungicides: benomyl (Benlate $50 \mathrm{WP}$ ), penycurone (Monceren $25 \mathrm{WP}$ ), cyproconazole (Alto $25 \mathrm{WP}$ ), toclosfosmethyle (Rizolex $10 \mathrm{WP}$ ) each $500 \mathrm{mg} / \mathrm{l}$ (S u m m e r, 1987; K a t a r i a, H of f m a n, 1988; K a t a r i a, G is i, 1989).

In comparative tests ( $\mathrm{V}$ i n c e $11 \mathrm{i}$, B e a u p r e, 1989) these media were rated equally effective in the selective recovery of Rhizoctonia spp. from soil and plant samples. Both media were dispensed at approximately $12 \mathrm{ml}$ per Petri dish (PD) ( $9 \mathrm{~cm}$ in diam.). The dishes with three selective media were used for plant samples assay. Tissue sections $1-1.5 \mathrm{~cm}$ long were cut from the margins of lesions, washed under tap water, rinsed with an antibiotic solution (10 mg chloramphenicol and 100 $\mathrm{mg}$ of neomycin per 11 of distilled water) and transferred aseptically to Ko-Hora medium and to two other selective media. After the tissues had been grown for 3 days at $21-22^{\text {u }} \mathrm{C}$ in the dark, cultures were examined at $400 \mathrm{x}$ for mycelia of $R$. solani.

$\mathrm{N}$ u c le a r s t a i $\mathrm{n}$ in g. Cultures on PDA were stained by a rapid technique with $0.5 \%$ aniline blue and by a HCL-Giemsa nuclear staining procedure, which to allowed count of nuclei in vegetative cells ( $\mathrm{He}$ r $\mathrm{r}, 1979$ ).

Hy phal an as to mos is. Hyphal anastomosis was observed on agar-coated slides. All the wheat culm isolates were paired with GAG-1 and AG-4 tester isolates to determine their affinities. Isolates of $R$. cerealis, $R$. solani were paired in all possible combinations with representative isolate from deseased culms. GAG-1 ( $R$. cerealis) tester isolate was provided by Prof. Burpree, Canada and AG-4 by Prof. Carling, USA. 
Growth rate and characteristics of colonies. Agar discs (5-7 mm in diam.) cut from margin of actively growing colonies on PDA were transferred to PD containing $15 \mathrm{ml}$ of PDA freshly prepared from potatoes. Three dishes of each isolate were incubated at $22-23^{\circ} \mathrm{C}$ in the dark. Two measurements at right angles were taken and the increase in colony diameter between 24 and 48 hour of growth was recorded. The morphology and colour of colonies were compared during the first week of growth and after 24 days.

Pathogen icity tests. Oat kernel inoculum was prepared by autoclaving $100 \mathrm{ml}$ of whole oat kernels and $50 \mathrm{ml}$ of distilled water in a $250 \mathrm{ml}$ Erlenmeyer flask for 1 hour on two consecutive days. Colonised agar dises of isolate tested were transferred to flasks and incubated at $23-26^{\circ} \mathrm{C}$ for $14-21$ days prior to use. Seeds of spring wheat cv. 'Inga' were surface sterilized in a $95 \%$ ethyl alcohol for 30 seconds, then rinsed with sterile water and planted wet on sterile sand in a plastic pot $15 \mathrm{~cm}$ diam. Five replicate pots were used per isolate. Seedlings were inoculated by placing one infected oat kernel $1 \mathrm{~cm}$ below the sand in contact with the coleoptile. After 21 days, plants were washed free of adhering sand and rated for development of lesions.

The ability of isolates of Rhizoctonia sp. obtained from culms to cause root-rot was tested using inoculum layer technique ( $\mathrm{L}$ i p p s, H e r r, 1982). Plastic pots with sterile sand as described above were used. A completely colonized $2 \%$ WA layer inoculum from a PD culture was placed to cover the top of the sand. A noncolonized agar layer was used for the control. Seven surface-sterilized wheat seeds were arranged on top of the agar inoculum and then covered with $50 \mathrm{ml}$ of the sand. Five replicate pots were randomized and plants were maintained at $10-25^{\circ} \mathrm{C}$. Seedlings were washed free of adhering sand and both root length and fresh weight of tops were recorded.

Ag a r - plate virulence as s a y. Seeds were washed in a $0.3 \%$ sodium hypochlorite solution in deionized water for 5 minutes, rinsed in deionized water and air-dried before use. The seeds were placed in a circle $1 \mathrm{~cm}$ from the edge of a $15 \mathrm{~cm}$ diam. sterile, disposable PD $15 \mathrm{~cm}$ in diam. containing $20 \mathrm{ml}$ of $1.5 \%$ WA. About $1 \mathrm{~mm}$ diam. mycelial disc from the edge of a 2-3 day old $1.5 \%$ WA culture of each of the isolates was transferred aseptically to the centre of each disc (one/disc). Control plates have a noncolonized agar dishes.

Two days after inoculation, 3-5 drops of sterile distilled water were dispensed aseptically onto each seed. Dishes were sealed at two points with clear adhesive tape and incubated in continous darkness at room temperature for 5 days. Dishes were then placed in a laboratory and opposed to light for 12 hours (one day). The percentage of seedlings with infected roots and/or coleoptile and disease severity on individual seedlings was recorded 9 days after inoculation. Disease severity was rated based on a $1-5$ scale: $1=$ no symptoms, normal root development; $2=$ localized tissue discoloration without necrosis, near-normal root development; $3=$ localized lesions with extensive tissue discoloration, near-normal root development; $4=$ nearly 
complete root necrosis, partially restricted root legth; and $5=$ complete root-rot, length severely restricted. A dishe containing 10 seedlings represented one replication. The experiment was conducted four times, with each repetition in time representing one block of randomized complete design.

\section{RESULTS}

Altogether 110 isolates belonging to Rhizoctonia spp. were isolate from wheat culms with sharp eyespot lesions. Among these isolates $61 \%$ were assigned to $R$. cerealis (GAG-1), $22 \%$ to AG-4 while $17 \%$ were unassignable to any of the anastomosis group. These isolates did not anastomosed neither with tester GAG-1, or with the tester of AG-4 and all had binucleate hyphal cells. All the isolates from wheat which anastomosed with tester GAG-1 had binucleate cells. All the isolates of Rizoctonia solani Kühn anastomosing with testers AG-4 had 5-7 nuclei per cell. Using hyphal anastomosis tests, hyphae of wheat isolates of $R$. cerealis and of the GAG-1 tester isolate fused with one another. Wheat isolates of $R$. solani belonging to AG-4 group fused with AG-4 tester isolates, confirming common anastomosis affinities among isolates tested. Other wheat isolates of binucleate Rhizoctonia spp. failed to anastomose with the GAG-1 tester and one another.

$\mathrm{C}$ h a r a cteristics of $\mathrm{col}$ on i es. All the binucleate isolates of Rhizoctonia obtained from wheat culms formed yellow-white to light-tan coloured mycelium on PDA during the first week of growth. In some cultures, mycelial pigmentation increased with age, resulting in light-tan coloration after 23 days of growth. Sclerotial development varied greatly among isolates. Some produced or no very few sclerotia and others formed many darkly pigmented sclerotia covering the agar surface. Some isolates which failed to anastomose with CAG-1 produced no sclerotia covering hyphal remained yellow-white during 24 days of the study. Hyphae of all the wheat isolates studied ranged from 3.0-7.5 $\mu \mathrm{m}$ in diameter. Most of the isolates of $R$. cerealis had white-cream mycelium which remained creamy even after 3 weeks.

G row th $\mathrm{r}$ a te $\mathrm{s}$. The growth rate of the CAG-1 tester isolate $(11 \mathrm{~mm} / 24 \mathrm{~h})$ was within the range of growth raters of the wheat isolates that were assigned to CAG-1 (10.7-11.5 mm/24 h). Some isolates of $R$. cerealis grew slowly than the tester CAG-1 $(7.4 \mathrm{~mm} / 24 \mathrm{~h})$. The binucleate isolates which failed to anastomose with tester isolates GAG-1 grew slowly than the GAG-1 isolates ( $14.9 \mathrm{~mm} / 24 \mathrm{~h})$.

The multinucleate isolates of $R$. solani Kühn belonging to anastomose group AG-4 grew about three times as fast as the wheat isolates assigned to GAG-1 ( $R$. cerealis) and other binucleate isolates of Rhizoctonia spp. (24.2-28.8 mm/24 h). The growth rate of the AG-4 tester isolate was $29.8-30 \mathrm{~mm} / 24 \mathrm{~h}$. The isolates of AG-4 had width hyphae 5.2-8 $\mu \mathrm{m}$ in diam. on average. The width of the hyphae of 
$R$. cerealis varied considerably and an average hyphal width of $R$. cerealis was significantly lower than that of the all isolates of $R$. solani anastomose group AG-4 [hyphae $<5 \mu \mathrm{m}$ in diam. (mean 4-5 $\mu \mathrm{m}$ )].

On PDA colonies of AG-4 isolates were white to cream coloured after 4-6 days of growth. Initial colony growth was dense and spidery. Small sclerotia $(<1.0 \mathrm{~mm}$ in diam.) were dispersed over the surface of cultures. After 14 days of growth colonies of AG-4 isolates were tan to chocolate brown. Nonrinded chocolate brown sclerotia (2-5.2 $\mathrm{mm}$ in diam.) were dispersed over the surface of cultures. Some isolates of AG-4 (ca 2-3\%) had a fluffy appearance on PDA, with abundant aerial tan or chocolate brown mycelium and tufts of monilioid cells adhering to the PD lids.

$\mathrm{Path}$ oge n i c ity test $\mathrm{s}$. All the binucleate isolates of Rhizoctonia cerealis (GAG-1) which caused sharp eyespot disease of wheat in the field were pathogenic to wheat seedlings indicating that they were $R$. cerealis (GAG-1). Wheat stems sharply definied with dark-brown margins lesions with creamy central areas were observed in the field. Lesions frequently coalesced into larger multiple patches, extending up stems for several centimeters or girdling the stems. One or more tillers per plant were usually killed prematurely due to the development of sharp eyespot lesions. Death of tillers caused the heads to lose colour resulting in the white-head symptoms.

Variation was found in the virulence of binucleate isolates of Rhizoctonia sp. using the wheat seedling assay. Wheat isolates anastomosing with the GAG-1 tester isolate produced sharp eyespot lesions on wheat seedlings but significant differences in the severity of disease occurred. Other of the binucleate isolates of Rhizoctonia spp. which failed to anastomose with the GAG-1 tester were non-pathogenic and caused only slight browning on some seedlings. None of the wheat isolates of R. cerealis (GAG-1) caused visible root-rot, root stunting or reduction of the top growth o seedlings when roots were allowed to grow through an agar layer colonized by the fungi-tested. Isolates of AG-4 were less pathogenic to wheat compared with $R$. cerealis isolates. Wheat isolates that anastomosed with the AG-4 tester isolate produced sharp eyespot lesions on wheat seedlings but several of AG-4 did not produce symptoms. Some tested isolates of AG-4 caused root-rot on wheat seedlings.

\section{DISCUSSION}

The results of this study indicate that the pathogenic binucleate isolates of Rhizoctonia spp. obtained from wheat culms with sharp eyespot lesions identified as $R$. cerealis as described by $\mathrm{V}$ a $\mathrm{n}$ d e $\mathrm{rH}$ o e $\mathrm{ve} \mathrm{n}$ and $\mathrm{B}$ o $1 \mathrm{l}$ e $\mathrm{n}(1980)$. The morphology of the wheat isolate cultures paralleled was similar to that of $R$. cerealis reported previously but more variation in colour was detected. Considerable variation in sclerotial production occurred among different isolates of $R$. cerealis from wheat. B u r p r e e (1980) also found sclerotia production to be of limited taxonomic 
value. The growth rate of the CAG-1 tester isolate was similar to that of the isolates from wheat. Binucleate isolates which failed to anastomose with the CAG-1 tester isolate grew somewhat faster than the $R$. cerealis isolates. These results indicate that growth rate may facilitate separation of $R$. cerealis from other binucleate isolates. Burpree(1980), Murray, Burpree(1984), Oniki, Ogoshi, Araki (1986), Kataria and $\mathrm{H}$ of $\mathrm{m}$ an (1989), Mordue, Currah, B ridge (1989) and B u r pree, M a r t in (1992) also suggested that hyphal anastomosis and host specificity would be valuable characters for identifying $R$. cerealis. In an anastomosis test, hyphal fusion occurred between isolates of $R$. cerealis paired in all possible combinations regardless of their origin. When tested for pathogenicity, only isolates which anastomosed with CAG-1 were pathogenic to wheat seedlings. These findings also support the results of B u r p r e e (1980)), M u r r a y, B u r p r e e (1984), Oniki, Ogoshi, Araki (1986), Kataria, Hof f man (1989), B urpree and $\mathrm{M}$ a r $\mathrm{t}$ i $\mathrm{n}$ (1992) indicating that isolates of $R$. cerealis comprise a common anastomosis group CAG-1.

Other binucleate isolates of Rhizoctonia sp. obtained from wheat culms produced no symptoms on inoculated seedlings.

These binucleate isolates of Rhizoctonia spp. may have been present on the diseased culms together with $R$. cerealis (GAG-1) and $R$. solani anastomose group AG-4. Because none of these isolates anastomosed with any of the CAG tester isolates, further investigations should be conducted to identify them.

S ter $\mathrm{n}$ and J on es (1987) reported that most of the isolates of Rhizoctonia sp. obtained from diseased wheat culms anastomosed with the AG-4 tester isolate of $R$. solani and that pathogenicity trials proved that the $R$. solani $\mathrm{AG}-4$ isolates caused sharp eyespot lesions on wheat plants grown in fields and in greenhouse. These and other results of studies with $R$. solani and $R$. cerealis indicate that two different fungi species may cause sharp eyespot lesions on cereals. Taking under consideration the above results nuclear staining and observations of hyphal anastomosis is recomended to be used for differentiating isolates of Rhizoctonia spp. from wheat and other cereals. Par a me ter, W h it ne y, Plat t, 1967; Parameter, Sherwood, Plat t, 1969; Parameter, 1970; Og os h i, 1975, 1985; Her r, 1979; B urpree, 1984; Oniki, Ogoshi, Araki, 1986; Mordue, Currah, Bridge, 1989).

Considerable variation in the ability of isolates to parasite roots and culms of cereals has been reported. It has been observed that isolates identified as $R$. solani produced two distinct types of injuries on wheat plants. Isolates from England caused severe root-rot whereas those from Canada, the United States and Australia attacked only the lower culms of wheat plants. The results of the present study and the findings of B r u e h I (1951), P i t (1964), S te r n, J o n e s (1978) and Lip p s, H e r r (1981) indicate thak isolates from sharp eyespot lesions do not attack roots. The authors reported a severe root-rot of wheat caused by multinucleate isolates 
of $R$. solani anastomose groups AG-2-2, AG-4 and AG-8. They also indicated that although roots were severely rotted, culms were never affected by these anastomosis groups of $R$. solani. In view of reports of $R$. solani attacking roots and culms of cereals and the relatively recent use of nuclear staining and hyphal anastomosis as an aid in differentiating isolates and species of Rhizoctonia sp. A comparative study should be conducted to determine which isolates or species $R$. cerealis and $R$. solani attack roots and/or culms of plants in Poland.

Acknowledgements. We thank Professor B u r p r e e for providing tester strain AG-I and Professor $\mathrm{C}$ a r l ing for providing tester strain AG-4.

Research supported by a grant No 5P06 B 208 from the Polish Committee of Scientific Research (KBN).

\section{REFERENCES}

B I a ir I. D., 1942. Studies on the growth in soil and the parasitic action of certain Rhizoctonia solani isolates from wheat. Can. J. Res. 20: 174-185.

B oe re ma G. H., Verh oeve n A.. 1977. Check-list for scientific names of common parasitic fungi. Ser. 2b Fungi in field crops: Cereals and Grasses. Netherl. J. Plant Pathol. 83: 165-204.

B r u e h 1 G. W., 1951. Rhizoctonia solani in relation to cereal crown and roots rots. Phytopathology 41 : 375-377.

B u rpree L. L., 1980. Rhizoctonta cerealis causes yellow patch to turfgrass. Plant Dis. 64: 1114-1116.

B u rpree L. L., M a rt in B., 1992. Biology of Rhizoctonia species associated with turfgrasses. Plant Dis. 76: $112-117$.

Burpree L. L., Sanders P. L., Cole H., Jr., Sherwood R. T., 1980. Anastomosis groups among isolates of Ceratobasidium comigerum and related fungi. Mycologia 72: 689-701.

Ca r l ing D. E., Le in er R. H., K e b I e r K. M., 1986. Characterization of Rhizectonia solani and binucleate rhizoctonia-like fungi collected from Alaskan soils with varied crop histories, Can. J. Plant Pathol. 8: 305-310.

Carl ing D. E., Sum me r D. R., 1992. Rhizoctonia. Amer. Phytopathol. Soc. St. Paul MN.

C a s t r o C., 1982. Methods for the quantitative estimation of Rhizoctonia solani from soil. Ph. D. Thesis. Univ. Idaho, Moscow.

Cl a r ks on J. D., C o ok R. J., 1983. Effect of sharp eyespot (Rhizoctonia cerealis on yield losses in winter wheat). Plant Pathol. 32:421-428.

De a c on J. W., S cott D. B., 1988. Rhizoctonia solani assocated with crater disease (stunting) of wheat in South Africa. Trans. Br. Mycol. Soc. 85: 19-327.

Gl y n n e M. D., 1950. Sharp eyespot as a severe disease of oats. Nature 166:232.

G I y n n e M. D., R i t ch i e W. M., 1943. Sharp eyespot of wheat caused by Corticium (Rhizoctonia) solani. Nature 152: 161 .

Hen is Y., Ghaffar A., Baker R., Gillespie S. L., 1978. A new pellet soil-sampler and its use for the study of population dynamics of Rhizoctonia solani in soil. Phytopathology 68: 371-376.

H e r r L. J., 1979. Practical nuclear staining procedures for rhizoctonia-like fungi. Phytopathology 69 : 958-961,

Hollins T. W., Jellis G. J., S cott P. R., 1983. Infection of potatoes and wheat by isolates of Rhizoctonia solani and Rhizoctonia cerealis. Plant Pathol. 32: 303-310.

H o 11 i s s. W., S cott P. R., 1983. Resistance of wheat cultivars to sharp eyespot caused by Rhizoctonia cerealis. Ann. Appli. Biol. 102:126-127.

Kat a r i a M. A., G is i U., 1989. Recovery from soils and sensitivity to fungicides of Rhizoctonia solani and Rhizoctonia cerealis. Mycol. Res, 92*485-492. 
Kat a ri a M. A., H of $\mathrm{f} m$ a n G. M., 1988. A critical review of plant pathogenic species of Ceratobasidium Rodgers. J. Plant Dis. Protect 95: 81-107.

Ko W. H., Hor a F, K., 1971. A selective medium for the quantitative determination of Rhizoctonia solani in soil. Phytopathology 61: 707-710.

Li p s . P. E., Herr L. J., 1981. Rhizoctonia cerealis causing sharpeyespot of wheat in Ohio. Phytopathology 71: 690-691. - 1982. Etiology of Rhizoctonia cerealis in sharp eyespot of wheat. Ibid. 72: $1574-1577$.

M a rti n S. B., L u c a s L. T., 1984, Characterization and pathogenicity of Rhizoctonia spp. and binucleate rhizoctonia-like fungi from turf grasses in Northern Carolina. Phytopathology 74: 170-175.

M o e n R., H a r $\mathrm{r}$ is J. R., 1985. The Rhizoctonia disease complex of wheat and barley. [In:] Ecology and Management of soilbome Plant Diseases. Amer. Phytopathol. Soc. St. Paul.

Mordu e J. B., Currah R. S., B ridge P. D., 1989. An intergrated approach to Rhizoctonia taxonomy cultural, biochemical and numerical techniques. Mycol. Res. 92: 78-79.

M u r a y D. I. B u r pree L. L., 1984. Ceratobasidium cereale sp. nov., the teleomorph of Rhizoctonia cerealis. Trans. Brit. Mycol. Soc. 82: 170-178.

Og os h i A., 1972. Some characteristics of hyphal anstomosis groups in Rhizoctonia solani Kühn. Ann. Phytopathol. Soc. Japan, 38: 123-129.

O gos h i A., 1975. Studies on the anastomosis groups of Rhizoctonia solant Kühn and on their perfect stage. Bull. Nat. Inst. Agric. Sci. Ser. C. 30: 1-63.

Ogosh i A., 1985. Anastomosis groups of Rhizoctonia solani Kühn and binucleate Rhizoctonia. [In:] Ecology and Management of soilbome Plant Diseases. Amer. Phytpathol. Soc. St. Paul.

Ogos h i A. Cook R. J., B asset E. N., 1990. Rhizoctonia species and anastomosis groups causing root-rot of wheat and barley in the Pacific Northwest. Phytopathology 80: 784-788.

Ogosh i A.. Oniki M., Araki T., 1983. Anastomosis groups of binucleate Rhizoctonia in Japan and North America and their perfect states. Trans. Mycol. Soc. Japan, 24:79-87.

Ogoshi A., Oniki M., S a $\mathrm{k}$ a i R., 1979. Anastomosis grouping among isolates of binucleate Rhizoctonia. Trans. Mycol. Soc. Japan, 20: 33-39.

On ik i M., O gos h i A.. A raki T., 1986. Ceratobasidiam setariae, C. comigerum and $C$. graminearum the teleomorph of the pathogenic binucleate Rhizoctonia fngus from gramineaous plants. Trans. Mycol. Soc. Japan. 27: 147-158.

P a r a m e te r J. R.. Jr. [ed.], 1970. Rhizoctonia solani: Biology and pathology, Univ. California Press, Berkeley, p. 255.

$\mathrm{P}$ a r a m e ter J. R. Jr., S her wood R. T., P I a t t W. D., 1969. Anastomosis grouping among isolates of Thanatephorus cucumeris. Phytopathology 59: 1270-1278.

P a r a m e ter J. R. Jr.. Whitney H. S., Platt W. D., 1967. Affinities of some Rhizoctonia species that resemble mycelium of Thanatephorus cucumeris. Phytopathology 57: 218-223.

P i t t D., 1964. Studies on sharp eyespot of cereals. I. Disease symptoms and pathogenicity of isoaltes of Rhizoctonia solani Kuhn and the influence of soil factors and temperature on disease development. Ann. Appl. Biol. 54: 77-89.

Re in ecke P., Fe h rma n $\mathrm{H} ., 1979$. Infection experiments with Rhizoctonia cerealis van der Hoeven on cereals. J. Plant Dis. Prot. 86: 241-246.

Scott D. B., Visser C. P. N., Ruzen a c h t E. M. C., 1979. Crater disease of summer wheat in African drylands. Plant Dis. Rep. 63:836-840.

S h e r w o o d R. T., 1969. Morphology and physiology in four anastomosis groups of Thanatephorus cucumeris. Phytopathology 59: 1924-1929.

Sneh B., Burpree L., Ogosh i A., 1991, Identification of Rhizoctonia species. Amer. Phytopathol. Soc. St. Paul.

S pra g u e R., 1934. Preliminary note on another foot rot of wheat and oats in Oregon. Phytopathology $24:$ 946-948. - 1937. A further note on the fungus causing a white root rot of wheat and oats. lbid. 27: 798-800.

St ern R. E., J on es J. P., 1978. Sharp eyespot of wheat in Arkansas caused by Rhizoctonia solani. Plant. Dis. Rep. 62: 56-60.

$\mathrm{S} u \mathrm{~m} \mathrm{~m}$ e r D. R. 1987. Efficay of penycuron against isolates representing different anastomosis groups of Rhizoctonia solani and Rhizoctonia like binucleate fungi. Plant Disease 71:515-518. 
Truijo E., Cavin C. A, A ragaki M., Yosh imura M. A., 1987. Ethanol-potassium nitrate medium for enumerating Rhizoctonia like fungi from soil. Plant Disease 71: 1098-10100.

Van der Hoeve n E. P.. B olle n G. J., 1980. Effect of benomyl on soil fungi associated with rye. I. Effect on the incidence of sharp eyespot caused by Rhizoctonia cerealis. Neth. J. Plant Pathol. 86: 163-180.

$V$ inc ell i P. C., B e a u pre C. M.+ 1989. Comparison of media for isolating Rhizoctonia solani from soil. Plant Disease 73: 1014-1017.

\title{
Grupy zgodności wegetatywnej grzybów z rodzaju Rizoctonia spp. wywołujących łamliwość źdźbła pszenicy
}

\author{
Streszczenie
}

Z porażonych rostin pszenicy z objawami łamliwości zdżbla wyosobniono wielojądrowe i dwujądrowe izolaty Rizoctonia spp. Przynależnosé izolatów do grup zgodnosci wegetatywnej oznaczono na podstawie ich zdolnosci do tworzenia heterokarionow z testerami. Stwierdzono, ze tamliwosc byla wywolana glównie przez dwujądrowe izolaty $R$. cerealis Van den Hoeven [st. dosk. Ceratobasidium cereale Murray et Burgee] należące do grupy zgodności wegetatywnej GAG-1. Lamliwośc źdźbła pszenicy byla równiez wywolana przez wielojłdrowe izolaty Rizoctonia solani Kühn [st. dosk. Thanatheporus cucumeris (Frank) Donk] należące do grupy zgodności wegetatywnej AG-4. W pracy podano charakterystykę obu izolatów. 